\title{
THE EFFECT OF LEAFLET AND VIDEO METHODS OF HEALTH COUNSELING ABOUT INNECTICIDED GAMBUS IN MABODO PRIMARY HEALTH CARE
}

\author{
Zanuma $^{1}$, Timbul Supodo ${ }^{2}$, Sanihu Munir ${ }^{3}$, Anry Hariadhin Depu ${ }^{4}$ \\ ${ }^{1234}$ Universitas Mandala Waluya, in Kendari Southeast Sulawesi Province, Indonesia
}

Corresponding Author : Zanuma

Email : skmzanuma@gmail.com

\section{Abstract}

Background: Mabodo is one of the Primary health cares where had the higher cases of malaria disease in 2018. The incident rate of malaria disease was 11.61 per 1,000 population. The incident increased in 9,387 / 1,000 population in 2019. This study aims to determine the effect of extension methods on changes in the behavior of pregnant women in the use of insecticidetreated mosquito nets in the working area of Mabodo Health Center, Muna Regency.

Methods:The research used quantitative research with, quasi-experimental study of a nonequivalent control group design.

Results: The statistical test results obtained $\mathrm{p}$ value $=0.000<0.05$ between groups, this indicates that there are differences in respondent knowledge in each group, there are differences in respondent attitudes in all groups with $\mathrm{p}$ value $=0.033<0.05$ between groups, there are differences in respondent attitudes all groups $\mathrm{p}$ value $=0.011<0.05$ between groups.

Conclusion: There is an effect of leaflet and video counseling on the use of textured bed nets in the working area of the Mabodo Health Center.

Key words: Malaria, Leaflets, Videos, Uses, Insecticide-treated Bed Nets 


\section{INTRODUCTION}

Malaria is a health problem in the world in the last decade. Eradicating malaria disease is one of the goals of the Global Sustainable Development Goals (SDGs). This global program by 2030 aims to end the malaria epidemic. (1). The World Health Organization (WHO) in 2016 there were 216 million cases of malaria in 91 countries with 445,000 deaths due to malaria(2).

The prevention of malaria is carried out by means of prevention and treatment with the aim of reducing malaria cases and deaths due to malaria and avoiding malaria outbreaks. In order to get maximum results, both prevention and treatment efforts must be done with good and comprehensive efforts(3). One way is by using insecticidetreated mosquito nets at bedtime. The proper and correct use of mosquito nets can protect people from mosquito bites that transmit malaria(4).

Southeast Sulawesi is one of the provinces in Indonesia that is included in the category of endemic areas. Of the 17 districts / cities in Southeast Sulawesi that have been eliminated, there are 9 districts / cities, so the number of malaria cases in Southeast Sulawesi tends to decline. This is according to data from the 2018 Southeast Sulawesi Provincial Health Office, the number of malaria cases in Southeast Sulawesi, as many as 916 with an API of 0.347 per 1,000 population2. Muna Regency is one of seven districts / cities in Southeast Sulawesi, which has not yet eliminated malaria in the last five years. In 2019 the number of malaria cases was 289 with API of 1.30 per 1000 population(5).

The Mabodo is the Health care centre with the most malaria cases found out of 28 Health care centre in Muna Regency in the last 2 years, with the 2018 API of 11.61 per 1,000 population and the 2019 API of 9,387 / 1,000 population. Malaria in pregnant women is also abundant in the Mabodo Health Center area, of the 12 Health care centre that provide antenatal care malaria services, the Mabodo Community Health
Center is still high in malaria cases, in 2018 the number of positive malaria cases for pregnant women was forty five (45) people with plasmodium falcifarum as many 25 people and Plasmodium vivax as many as 20 people. Data for 2019 on malaria cases for pregnant women were found thirty one (31) people, of one hundred and twenty one (121) pregnant women were screened for malaria at the first visit(6).

The results of the preliminary study show that on average pregnant women have not received clear information about the proper and correct use of bed nets, the distribution of bed nets for pregnant women is carried out at the Integrated Health care Center for pregnant women and babies with brief counseling and without the use of extension media so that it is less effective in delivering the information. to pregnant women is not well absorbed as a result of low knowledge of pregnant women about the use of bed nets. For this reason, researchers are interested in using leaflet extension methods and video playback as a health promotion against the use of insecticide-treated bed nets. This is what underlies researchers to intervene with leaflet and video outreach.

\section{METHOD}

The type of research used is quantitative research, namely Quasiexperimental research with a nonequivalent control group design(7). Both the experimental group and the control group were chosen randomly, the control class did not fully function to control the external variables that influenced the implementation of the experiment. The population was all pregnant women with a total of 60 people. and the research sample is a portion of the population which is considered to be representative of the entire population. Respondents were pregnant women who met the inclusion criteria, amounting to 58 people. The sampling technique in this study used probability sampling with a systematic 
sampling technique. By using the KrussKal Walis, Mann Whitney and Friedman statistical tests(8).

\section{RESULT}

Table 1 shows that before the intervention (pre test) 18 respondents (69\%) of respondents in the video group used mosquito nets in the poor category and 12 respondents $(71 \%)$ in the leaflet group who used mosquito nets in the poor category. After the intervention (post test) there was a change, 15 respondents (58\%) in the video group using mosquito nets were in the good category and 10 respondents (59\%) in the leaflet group were in the good category. Respondents in the control group at the time of the pre-test the use of mosquito nets which were classified as less were $12(80 \%)$ and at the time of the post test were 6 respondents $(40 \%)$ with the use of mosquito nets in the good category.

Table 2 shows that at the end of the measurement time all respondents experienced an increase in their knowledge score compared to the initial measurement. This shows that there are differences in the use of the pre test compared to the post test I, II, and III. The results of the Friedman test analysis showed $\mathrm{p}$ value $=0.000$ for all groups. This shows that there are differences in the use of respondents in each intervention group and the control group. To compare the significant differences between the intervention and control groups, the KruskalWallis test was used.

Table 3 shows the Kruskal-Wallis test which results obtained $\mathrm{p}$ value $=0.011$ $<0.05$ between groups, this indicates a difference in the use of respondents in each group. The highest increase in scores was in the video intervention group, leaflets and the lowest was in the control group.

Table 4 shows the results of the Mann-Whitney $U$ test that at the time of the pre test there were differences in the use scores in the video and leaflet and video and control groups. In the post test I there was no difference in the use scores in the group, in the post test II only on the leaflet and control there were differences in scores and in the post test III there was a difference in the scores for the use of respondents in the video and control groups.

Table 1

Descriptive of Changes in the Use of Mosquito Nets in Groups Intervention and Control

\begin{tabular}{|c|c|c|c|c|c|c|c|c|c|c|c|c|}
\hline \multirow{4}{*}{$\begin{array}{c}\text { Use of } \\
\text { mosquito } \\
\text { nets }\end{array}$} & \multicolumn{12}{|c|}{ Changes in the Intervention and Control Group } \\
\hline & \multicolumn{4}{|c|}{ Video Group } & \multicolumn{4}{|c|}{ Leaflet group } & \multicolumn{4}{|c|}{ Control Group } \\
\hline & \multicolumn{2}{|c|}{ Pre test } & \multicolumn{2}{|c|}{ Post test } & \multicolumn{2}{|c|}{ Pre test } & \multicolumn{2}{|c|}{ Post test } & \multicolumn{2}{|c|}{ Pre test } & \multicolumn{2}{|c|}{ Post test } \\
\hline & $\mathrm{n}$ & $\%$ & $\mathrm{n}$ & $\%$ & $\mathrm{n}$ & $\%$ & $\mathrm{n}$ & $\%$ & $\mathrm{n}$ & $\%$ & $\mathrm{n}$ & $\%$ \\
\hline Good & 0 & 0 & 15 & 58 & 0 & 0 & 10 & 59 & 0 & 0 & 6 & 40 \\
\hline Enough & 8 & 31 & 11 & 42 & 5 & 29 & 7 & 41 & 3 & 20 & 9 & 60 \\
\hline Less & 18 & 69 & 0 & 0 & 12 & 71 & 0 & 0 & 12 & 80 & 0 & 0 \\
\hline Total & 26 & $\begin{array}{c}10 \\
0\end{array}$ & 26 & $\begin{array}{c}10 \\
0\end{array}$ & 17 & $\begin{array}{c}10 \\
0\end{array}$ & 17 & $\begin{array}{c}10 \\
0\end{array}$ & 15 & $\begin{array}{c}10 \\
0\end{array}$ & 15 & $\begin{array}{c}10 \\
0\end{array}$ \\
\hline
\end{tabular}


Zanuma, Supodo, T., Munir, S., \& Depu, A. H.

DOI: 10.36566/ijhsrd/Vol3.Iss1/57

https://ijhsrd.com/index.php/ijhsrd

e- ISSN: $2715-4718$

Table 2

Change in the Score of Respondents in Each Group

\begin{tabular}{|c|c|c|c|c|c|c|}
\hline Use & $\begin{array}{c}\text { Measurement } \\
\text { Time }\end{array}$ & Mean & $\begin{array}{l}\text { Standard } \\
\text { Deviation }\end{array}$ & $\begin{array}{c}P- \\
\text { value }\end{array}$ & $\begin{array}{c}\text { Statistic } \\
\text { test }\end{array}$ & $\begin{array}{l}\text { Table } \\
\text { Value } \\
\end{array}$ \\
\hline \multirow{4}{*}{$\begin{array}{c}\text { Video } \\
\text { Group }\end{array}$} & Pretest & 9.23 & 1.21 & \multirow{4}{*}{0,000} & \multirow{4}{*}{76,036} & \multirow{4}{*}{7,815} \\
\hline & Post test I & 11.35 & 0.94 & & & \\
\hline & Post test II & 12.08 & 0.93 & & & \\
\hline & Post test III & 13.23 & 0.82 & & & \\
\hline \multirow{4}{*}{$\begin{array}{l}\text { Leaflet } \\
\text { group }\end{array}$} & Pretest & 8.82 & 1.47 & \multirow{4}{*}{0,000} & \multirow{4}{*}{47,814} & \multirow{4}{*}{7,815} \\
\hline & Post test I & 11.41 & 0.94 & & & \\
\hline & Post test II & 11.88 & 1.32 & & & \\
\hline & Post test III & 13.18 & 0.95 & & & \\
\hline \multirow{4}{*}{$\begin{array}{l}\text { Control } \\
\text { Group }\end{array}$} & Pretest & 8.27 & 1.16 & \multirow{4}{*}{0,000} & \multirow{4}{*}{41,891} & \multirow{4}{*}{7,815} \\
\hline & Post test I & 10.87 & 0.99 & & & \\
\hline & Post test II & 11.33 & 1.18 & & & \\
\hline & Post test III & 12.20 & 1.15 & & & \\
\hline
\end{tabular}

Table 3

Analysis of Comparative Scores on the use of Intergroup Respondents

\begin{tabular}{|c|c|c|c|c|c|}
\hline Use & $\begin{array}{c}\text { Measurement } \\
\text { Time }\end{array}$ & Mean & $\begin{array}{c}P- \\
\text { value }\end{array}$ & $\begin{array}{c}\text { Statistic } \\
\text { test }\end{array}$ & $\begin{array}{l}\text { Table } \\
\text { Value }\end{array}$ \\
\hline \multirow[t]{4}{*}{ Video Group } & Pretest & \multirow{4}{*}{33.31} & \multirow{12}{*}{0.011} & \multirow{12}{*}{9,021} & \multirow{12}{*}{5,991} \\
\hline & Post test I & & & & \\
\hline & Post test II & & & & \\
\hline & Post test III & & & & \\
\hline \multirow[t]{4}{*}{ Leaflet group } & Pretest & \multirow{4}{*}{33.03} & & & \\
\hline & Post test I & & & & \\
\hline & Post test II & & & & \\
\hline & Post test III & & & & \\
\hline \multirow{4}{*}{$\begin{array}{l}\text { Control } \\
\text { Group }\end{array}$} & Pretest & \multirow{4}{*}{18.90} & & & \\
\hline & Post test I & & & & \\
\hline & Post test II & & & & \\
\hline & Post test III & & & & \\
\hline
\end{tabular}


Zanuma, Supodo, T., Munir, S., \& Depu, A. H. DOI: 10.36566/ijhsrd/Vol3.Iss1/57

https://ijhsrd.com/index.php/ijhsrd

e- ISSN: $2715-4718$

Table 4

Differences in use scores between groups

\begin{tabular}{|c|c|c|c|c|c|c|}
\hline \multicolumn{2}{|c|}{ Group } & $\mathbf{n}$ & $\begin{array}{l}\text { Mean } \\
\text { Rank }\end{array}$ & $\begin{array}{c}p- \\
\text { value }\end{array}$ & $\begin{array}{c}\text { Statistic } \\
\text { test }\end{array}$ & $\begin{array}{l}\text { Table } \\
\text { Value }\end{array}$ \\
\hline \multirow{3}{*}{ Pre test } & $\begin{array}{l}\text { Video } \\
\text { Leaflet }\end{array}$ & $\begin{array}{l}26 \\
17\end{array}$ & $\begin{array}{l}26.41 \\
18.53\end{array}$ & 0.0419 & 2,035 & 1,960 \\
\hline & $\begin{array}{l}\text { Video } \\
\text { Control }\end{array}$ & $\begin{array}{l}26 \\
15\end{array}$ & $\begin{array}{l}24.65 \\
14.67\end{array}$ & 0.0066 & 2,715 & 1,960 \\
\hline & $\begin{array}{l}\text { Leaflet } \\
\text { Control }\end{array}$ & $\begin{array}{l}17 \\
15\end{array}$ & $\begin{array}{l}18.21 \\
14.57\end{array}$ & 0.0726 & 98,500 & 75,000 \\
\hline \multirow{3}{*}{ Post test I } & $\begin{array}{l}\text { Video } \\
\text { Leaflet }\end{array}$ & $\begin{array}{l}26 \\
17\end{array}$ & $\begin{array}{l}24.12 \\
22.44\end{array}$ & 0.6583 & 0.442 & 1,960 \\
\hline & $\begin{array}{l}\text { Video } \\
\text { Control }\end{array}$ & $\begin{array}{l}26 \\
15\end{array}$ & $\begin{array}{l}22.92 \\
17.67\end{array}$ & 0.1383 & 1,482 & 1,960 \\
\hline & $\begin{array}{l}\text { Leaflet } \\
\text { Control }\end{array}$ & $\begin{array}{l}17 \\
15\end{array}$ & $\begin{array}{l}18.68 \\
14.03\end{array}$ & 0.1281 & 90,500 & 75,000 \\
\hline \multirow{3}{*}{$\begin{array}{c}\text { Post test } \\
\text { II }\end{array}$} & $\begin{array}{l}\text { Video } \\
\text { Leaflet }\end{array}$ & $\begin{array}{l}26 \\
17\end{array}$ & $\begin{array}{l}24.78 \\
21.32\end{array}$ & 0.3845 & 0.870 & 1,960 \\
\hline & $\begin{array}{l}\text { Video } \\
\text { Control }\end{array}$ & $\begin{array}{l}26 \\
15\end{array}$ & $\begin{array}{l}23.67 \\
16.37\end{array}$ & 0.0508 & 1,953 & 1,960 \\
\hline & $\begin{array}{l}\text { Leaflet } \\
\text { Control }\end{array}$ & $\begin{array}{l}17 \\
15\end{array}$ & $\begin{array}{l}18.35 \\
14.40\end{array}$ & 0.0158 & 67,000 & 75,000 \\
\hline \multirow{3}{*}{$\begin{array}{c}\text { Post test } \\
\text { III }\end{array}$} & $\begin{array}{l}\text { Video } \\
\text { Leaflet }\end{array}$ & $\begin{array}{l}26 \\
17\end{array}$ & $\begin{array}{l}24.40 \\
21.97\end{array}$ & 0.5257 & 0.635 & 1,960 \\
\hline & $\begin{array}{l}\text { Video } \\
\text { Control }\end{array}$ & $\begin{array}{l}26 \\
15\end{array}$ & $\begin{array}{l}24.79 \\
14.43\end{array}$ & 0.0050 & 2,806 & 1,960 \\
\hline & $\begin{array}{l}\text { Leaflet } \\
\text { Control }\end{array}$ & $\begin{array}{l}17 \\
15\end{array}$ & $\begin{array}{l}20.06 \\
12.47\end{array}$ & 0.0158 & 67,000 & 75,000 \\
\hline
\end{tabular}




\section{DISCUSSION}

\section{The Effect of Video Counseling on the Use of Insecticide Nets in Pregnant Women in the working area of Mabodo Health Center, Muna Regency}

The results showed that before the intervention (pre test) all (100\%) respondents in the video group had not used insecticidetreated bed nets. The use of insecticidetreated bed nets has increased significantly since the first time providing health education via video. This can be seen from the results of the pre test to the post test I which have a positive rank of 26 .

Measurement of the use of mosquito nets from pre test to post test II and pre test to post test III has increased overall. This proves that providing health education through video media has an effect on increasing the use of bed nets on a regular basis. The results showed that at the final measurement all respondents experienced an increase in their use score compared to the initial measurement (pre test). This shows that there are differences in use at the start of the measurement compared to the first, second and third post tests. The results of the Friedman test obtained $\mathrm{p}$ value $=0.000$, this indicates that there are differences in the use of respondents in each measurement.

Based on observations made, almost all respondents have used insecticide-treated bed nets properly and correctly, there is only one respondent or pregnant women who do not like the smell of the bed nets because of cravings. Many factors influence respondents in using insecticide-treated bed nets, including good knowledge, good intentions, reliable and easily accessible sources of information.(9). Knowledge is a very important domain in shaping a person's actions(10).

According to researchers, changes in the behavior of using insecticide-treated mosquito nets in respondents occurred due to the quality of stimuli or messages from instructors who used natural language. The quality of the communication resources of the extension agents will determine the success of the respondent's behavior change(11).

\section{The Effect of Leaflet Extension Methods on the Use of Insecticidal Mosquito Nets in Pregnant Women in the working area of Mabodo Health Center, Muna Regency}

The results showed that before the intervention (pre test) all respondents in the leaflet group (100\%) were not in good category with the use of insecticide-treated bed nets. The results of the evaluation of the use of bed nets until the last measurement were obtained by $59 \%$ of the leaflet group respondents in the good category in the use of insecticide-treated bed nets. Compared with the initial measurement (pre test), at the final measurement all respondents experienced an increase in the score of using mosquito nets. The results of the Friedman test obtained $\mathrm{p}$ value $=0.000$ in the leaflet group. This indicates that there is a difference in use at the beginning of the measurement compared to the first, second and third post tests.

Based on the results of the study, there was a difference in the scores on the use of the leaflet group of respondents. The use of insecticide-treated bed nets has generally increased since the first time the extension was given through leaflet media. This is obtained from the results of the pre test to post test I which has a positive rank of 17. Measurement of the use of mosquito nets from pre test to post test II and pre test to post test III has increased overall. This proves that the provision of health education through leaflet media has an effect on increasing the use of insecticide-treated bed nets.

Based on observations made, almost all respondents have fully used insecticidetreated bed nets properly. The score for the use of mosquito nets has increased significantly $(\mathrm{P}<0.05)$. This increase was due to the knowledge gained from providing leaflets about insecticide-treated bed nets in 
the form of good and correct use of insecticide-treated bed nets which can change the respondent's attitude to be positive. Therefore, in the end, respondents will take an action to change their behavior for the better in using insecticide-treated bed nets.

The use of mosquito nets is an activity or human activity that can be directly observed by outsiders(12). Measuring the use of mosquito nets can be done by directly observing the use of mosquito nets at the respondent's house at night and during the day when conducting interviews with respondents(13). Behavior is a form of response or reaction to stimuli or stimuli from outside the organism (person), but in response it is highly dependent on the characteristics or other factors of the person concerned.(14). This research is in line with(15) that the provision of health education through leaflet media has an effect on malaria prevention practices in earthquake victims.

\section{CONCLUSION}

Extension with video and leaflet methods has an effect on the use of nets with textiles in the working area of the Mabodo Health Center so that there is a need for counseling to the community about malaria, the function and how to use insecticidetreated nets on an ongoing basis by health workers.

\section{REFERENCES}

1. Anggraeni I, Nurrachmawati A. Malaria Dalam Kehamilan: Kualitatif Model Kepercayaan Kesehatan Di Muara Wahau Provinsi Kalimantan Timur. 2017.

2. Louis DN, Perry A, Reifenberger G, Von Deimling A, Figarella-Branger D, Cavenee WK, et al. The 2016 World Health Organization classification of tumors of the central nervous system: a summary. Acta neuropathologica. 2016;131(6):803-20.

3. Diaz GF. Hubungan Pengetahuan Dan Persepsi Kepala Keluarga Tentang Malaria Terhadap Perilaku Pencegahan Penularan Penyakit Malaria Di Wilayah Kerja Puskesmas Kori Kabupaten Sumba Barat Daya: Universitas Airlangga; 2018.

4. Sugiarto S, Hadi UK, Soviana S, Hakim L. efektivitas kelambu berinsektisida terhadap nyamuk an. sundaicus (diptera: culicidae) dan penggunaannya di desa sungai nyamuk, Kalimantan Utara. Spirakel. 2018;10(1):1-11.

5. Dinas Kesehatan Provinsi Sulawesi Tenggara. Cakupan Imunisasi. Sulawesi Tenggara2019.

6. Dinas Kesehatan Kabupaten Muna. Jumlah Kasus Malaria. Muna Sulawesi Tenggara2018.

7. Mackey A, Gass SM. Second language research: Methodology and design: Routledge; 2015.

8. Sugiyono. Statistik Nonparametris Untuk Penelitian. 2015.

9. Askar M, Yusuf M, Putri DE. Hubungan pengetahuan dan sikap dengan perilaku masyarakat terhadap pencegahan malaria di wilayah kerja puskesmas Barugaia Kabupaten Kepulauan Selayar. Jurnal Ilmiah Kesehatan Diagnosis. 2013;3(3):23-9.

10. Notoatmodjo S, Krianto T, Hassan A, Mamdy Z. Promosi kesehatan global. Jakarta: Rineka Cipta. 2013.

11. Nesi H. 21 ESP and Corpus Studies. The handbook of English for specific purposes. 2013:407.

12. Ujang S. Hubungan Pengetahuan Dengan Perilaku Masyarakat Tentang Pencegahan Penyakit Kaki Gajah (Filariasis) Di Rt 02, Rw 02, Dusun Krajan, Desa Caluk, Kecamatan Slahung, Kabupaten Ponorogo: Universitas Muhammadiyah Ponorogo; 2018. 
Zanuma, Supodo, T., Munir, S., \& Depu, A. H. DOI: 10.36566/ijhsrd/Vol3.Iss1/57

https://ijhsrd.com/index.php/ijhsrd

13. Ayun LL. Hubungan Antara Faktor Lingkungan Fisik dan Perilaku Dengan Kejadian Demam Berdarah Dengue (DBD) di Wilayah Kerja Puskesmas Sekaran, Kecamatan Gunungpati, Kota Semarang Tahun 2015: Universitas Negeri Semarang; 2015.

14. Notoatmodjo S. Promosi Kesehatan dan Perilaku Kesehatan (Cetakan V). Jakarta: Rineka Cipta. 2015.

15. Yulianti E, Jannah R, Khoiroh LM, Istighfarini VN. Briket Arang Tempurung Kawista (Limonia acidissima) Teraktivasi $\mathrm{NaOH}$ dengan Perekat Alami. al-Kimiya: Jurnal Ilmu Kimia dan Terapan. 2019;6(1):1-8. 